Document downloaded from:

http://hdl.handle.net/10251/148180

This paper must be cited as:

Berenguer, R.; Quijada, C.; La Rosa-Toro, A.; Morallón, E. (2019). Electro-oxidation of cyanide on active and non-active anodes: Designing the electrocatalytic response of cobalt spinels. Separation and Purification Technology. 208:42-50.

https://doi.org/10.1016/j.seppur.2018.05.024

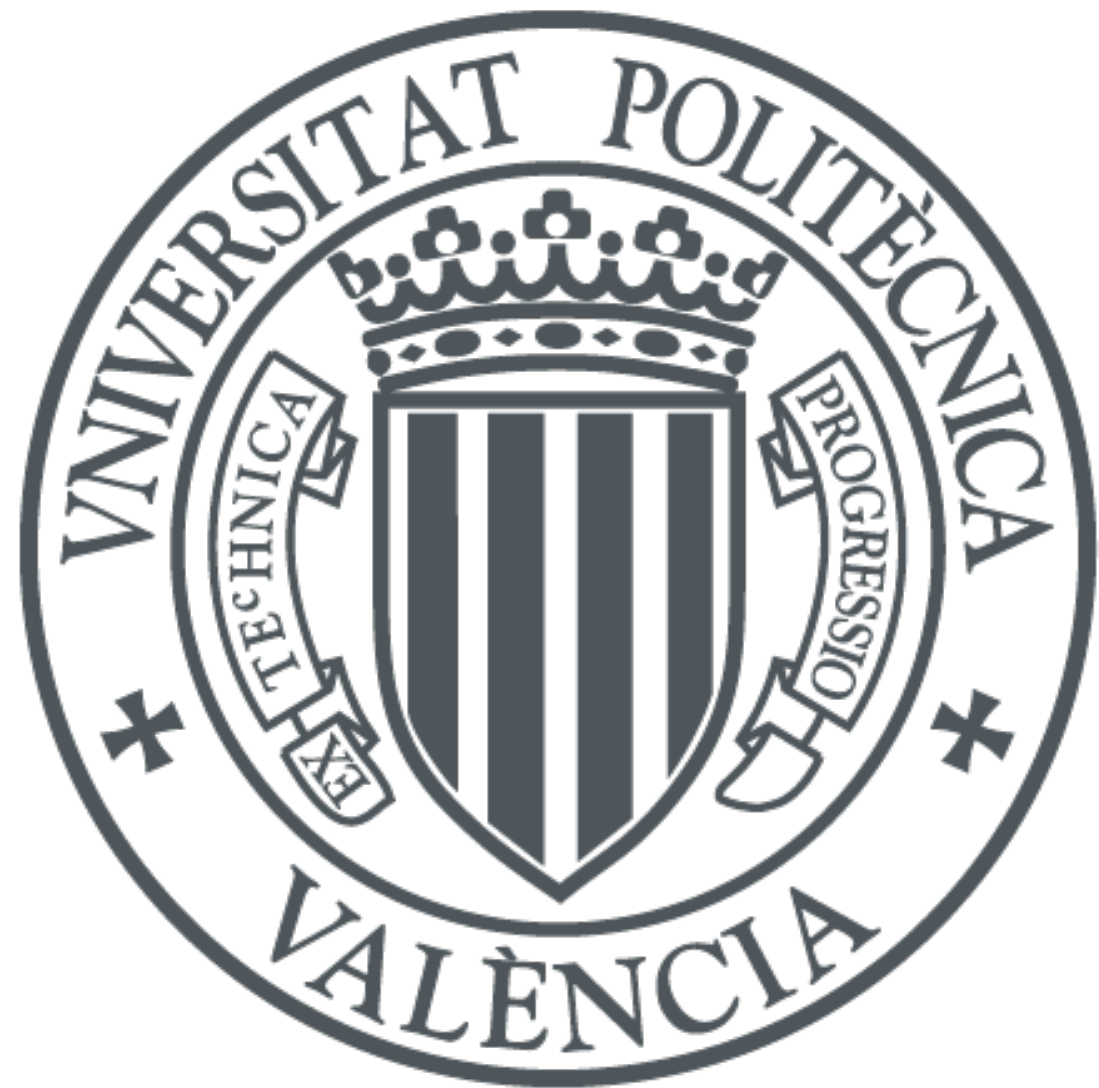

The final publication is available at

https://doi.org/10.1016/j.seppur.2018.05.024

Copyright Elsevier

Additional Information 


\title{
Electro-oxidation of cyanide on active and non-active anodes: designing the electrocatalytic response of cobalt spinels
}

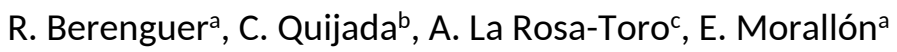 \\ a Instituto Universitario de Materiales, Departamento de Química Física, Universidad de \\ Alicante, Apartado 99, 03080-Alicante, Spain \\ b Departamento de Ingeniería Textil y Papelera, Universitat Politècnica de València. Pza. \\ Ferrándiz y Carbonell, 03801 Alcoy (Alicante). Spain \\ c Facultad de Ciencias, Universidad Nacional de Ingeniería, Av. Tupac Amaru, 210, Lima (Peru)
}

\begin{abstract}
The feasibility of the electrochemical technologies for wastewater treatment greatly relies on the design of efficient but inexpensive electrocatalysts. It is generally accepted that the socalled "non-active" anodes (like the boron-doped diamond (BDD) or $\mathrm{SnO}_{2}$-based anodes), producing highly oxidizing hydroxyl radicals, are the most promising candidates for pollutants abatement. In this work, the electrocatalytic performance of various cobalt oxides, pure and doped with $\mathrm{Cu}$ or $\mathrm{Au}$, for $\mathrm{CN}^{-}$oxidation has been studied and compared with that of conventional graphite, $\mathrm{BDD}, \mathrm{SnO}_{2}-\mathrm{Sb}$ and $\mathrm{SnO}_{2}$-Sb-Pt. The metal oxide electrodes were prepared by thermal decomposition of the salt precursors onto Ti. For the $\mathrm{M}$-doped $\mathrm{Co}_{3} \mathrm{O}_{4}$ electrodes, the nominal $\mathrm{M} / \mathrm{Co}$ ratios were $\mathrm{Cu} / \mathrm{Co}=0.07-1.00$; and $\mathrm{Au} / \mathrm{Co}=0.05-0.20$. The electrodes were characterized by different techniques (XRD, SEM, EDX, XPS) and their electrocatalytic response was studied by cyclic voltammetry and galvanostatic electrolysis in a $\mathrm{H}$-type cell in aqueous $0.1 \mathrm{M} \mathrm{NaOH}$. The obtained results show that the nature of the dopant plays a key role on the electrocatalytic behavior of cobalt spinels. Thus, while Cu catalyzes the $\mathrm{CN}^{-}$electro-oxidation, Au declines it. This is explained by the fact that, unlike Au (which segregates as Au-rich particles), $\mathrm{Cu}$ is effectively incorporated into the spinel structure by forming a solid solution $\left(\mathrm{Cu}_{\mathrm{x}} \mathrm{CO}_{3-\mathrm{x}} \mathrm{O}_{4}\right)$. In this solid solution, atomic scale $\mathrm{Cu}_{\text {(spinel) }} \mathrm{CNN}^{-}$specific interactions occur to catalyze the reaction, whereas in segregated $\mathrm{Au}$ particles the oxidation is hindered probably by a too-strong adsorption of cyanide and/or its inaccessibility to oxide active sites. Electrolysis runs have revealed that "active" over-saturated Cu-doped spinels $(\mathrm{Cu} / \mathrm{Co}=1.00)$ exhibit higher current efficiencies than conventional graphite and "non-active" $\mathrm{BDD}$ and $\mathrm{SnO}_{2}$-based anodes. Hence, we hereby demonstrate that an inexpensive "active" electrocatalyst can show even higher efficiency than the most powerful BDD anode. These results highlight the significance of anode design in the application of the electrochemical technique for wastewater treatment.
\end{abstract}

Keywords: Electrochemical oxidation, Wastewater, Cyanide, Cobalt spinel, Active anode

Corresponding author

R. Berenguer

raul.berenguer@ua.es

Telf. +34-965902364 


\section{INTRODUCTION}

Because of its high toxicity and wide utilization in large scale industrial processes [1,2], cyanide is considered a priority pollutant by environmental protection agencies [3,4]. Among different methods for cyanide remediation [5,6], the anodic degradation allows its oxidation and/or mineralization under environmentally and practically matchless conditions: in-situ, at ambient pressure and temperature, and by using electrons as the only reagent $[7,8]$. At the same time, this method permits the recovery of precious metals on the cathode. Despite these advantages, the efficiency and cost, i.e. the feasibility, of the electro-oxidation treatments are determined by the choice of a suitable anode [7-9].

It is generally accepted that "non-active" anodes, like the boron-doped diamond (BDD) and the $\mathrm{SnO}_{2}$-Sb anodes, are the most effective for the complete oxidation of refractory molecules $[10,11]$. This is due to the capability of these materials to generate physisorbed hydroxyl radicals and other highly oxidizing species at high potentials, in detriment of a poor activity for the oxygen evolution reaction (OER). However, the utilization of BDD is limited by its high cost and fragility, and $\mathrm{SnO}_{2}$-Sb shows very poor electrochemical stability. On the other hand, "active" anodes, like transition metals and their oxides, present high stability but they are considered less efficient for the electro-oxidation of pollutants, because their good activity towards the competing OER and the lower oxidizing power of chemisorbed hydroxyl radicals, i.e. the redox-active species on the electrode. Another family of electrodes is formed by carbon materials (graphite, CNTs, graphene, etc.), but they suffer from partial oxidation and/or combustion (low stability) at moderate and high potentials. Hence, the design of efficient, inexpensive and stable anodes is a great challenge in chemistry [9]. In parallel, to be reliable, the development of novel electrodes claims comparative studies with well-known reference materials.

We have recently found that spinel-like $\mathrm{Cu}_{x} \mathrm{Co}_{3-x} \mathrm{O}_{4}$ electrodes exhibit high activity for $\mathrm{CN}^{-}$ oxidation [12]. Galvanostatic treatments in a filter-press cell showed that the catalytic activity for $\mathrm{CN}^{-}$oxidation remarkably increases with the $\mathrm{Cu}$ content, so that, $100 \%$ current efficiencies (CEs) were reported for saturated and over-saturated spinels. Such a very high CE is unprecedent for any electrode different to BDD. Even more surprisingly, this catalytic effect occurred together with a significant catalytic effect of $\mathrm{Cu}$ on the competing OER. This outstanding catalytic effect was experimentally justified and assigned to a specific interaction $\mathrm{Cu}_{\text {(spinel) }}{ }^{-} \mathrm{CN}^{-}$. Apart from the novelty, these results revived the interest for designing novel electrodes with specific dopant-pollutant interactions.

It is well-known that, like $\mathrm{Cu}$, Au shows a strong interaction with $\mathrm{CN}^{-}$and, therefore, attractive potentiality to be used as anode dopant for $\mathrm{CN}^{-}$electro-oxidation. In this work, various pure and $\mathrm{Au}$ - and $\mathrm{Cu}$-doped $\mathrm{CO}_{3} \mathrm{O}_{4}$ spinels have been prepared and investigated for their electrocatalytic activity towards $\mathrm{CN}^{-}$electro-oxidation in a $\mathrm{H}$-type divided electrochemical cell. In order to estimate the significance of their activity, the response of these anodes is compared with that of conventional graphite and "non-active" $\mathrm{BDD}$ and $\mathrm{SnO}_{2}-\mathrm{Sb}$ and $\mathrm{SnO}_{2}$-SbPt electrodes. Finally, the physicochemical and electrochemical properties of the different spinel anodes are thoroughly characterized and compared to evaluate the role of the dopant on the electrocatalytic behavior of the doped spinel. The obtained results are intended to support the paramount importance of electrocatalysts design for pollutants electro-oxidation. At the same time, they aim the scientific community to reconsider whether the "non-active" anodes are always the most efficient for this application. 


\section{EXPERIMENTAL}

\subsection{Electrode materials}

All the metal oxide anodes were prepared by thermal decomposition of the salt precursors onto Ti plates of $2 \mathrm{~cm}^{2}$ used as support. Pure $\mathrm{CO}_{3} \mathrm{O}_{4}$ and $\mathrm{Cu}$-doped $\mathrm{CO}_{3} \mathrm{O}_{4}$ (also called as $\mathrm{Cu}_{\mathrm{x}} \mathrm{CO}_{3-}$ ${ }_{\mathrm{x}} \mathrm{O}_{4}$ ) electrodes were prepared at $350{ }^{\circ} \mathrm{C}$ as reported before [13-15]. The salt precursors were $\mathrm{Co}\left(\mathrm{NO}_{3}\right)_{2} \cdot 6 \mathrm{H}_{2} \mathrm{O}$ (A.C.S Aldrich) and $\mathrm{Cu}\left(\mathrm{NO}_{3}\right)_{2} \cdot 3 \mathrm{H}_{2} \mathrm{O}$ (MERCK p.a.) dissolved in absolute ethanol (J.T Baker). The Au-doped $\mathrm{CO}_{3} \mathrm{O}_{4}$ anodes were obtained exactly with the same procedure [14,15], but using $\mathrm{HAuCl}_{4}$ (MERCK p.a.) as gold precursor. The nominal M/Co ratios were $\mathrm{Cu} / \mathrm{Co}$ $=0.07-1.00$ and $\mathrm{Au} / \mathrm{Co}=0.05-0.20$, respectively. On the other hand, $\mathrm{SnO}_{2}-\mathrm{Sb}$ and $\mathrm{SnO}_{2}-\mathrm{Sb}-\mathrm{Pt}$ anodes, with $\mathrm{Sb}=13 \%$ and $\mathrm{Pt}=3 \%$ (metal atomic percentage), were prepared at $400{ }^{\circ} \mathrm{C}$ by following a quite similar procedure [16]. In this case, $\mathrm{SnCl}_{4} \cdot 5 \mathrm{H}_{2} \mathrm{O}, \mathrm{SbCl}_{3}, \mathrm{H}_{2} \mathrm{PtCl}_{6} \cdot 6 \mathrm{H}_{2} \mathrm{O}$ (Fluka p.a.) were used as salt precursors. The graphite anode was purchased from Carbone Lorraine, whereas the BDD anode was obtained from the Centre Suisse d'Electronique et de Microtechnique SA (CSEM).

\subsection{Electrolysis of cyanide solutions}

The electrocatalytic activity of the different anodes towards $\mathrm{CN}^{-}$oxidation was studied by galvanostatic electrolysis in a $\mathrm{H}$-type cell by using aqueous $0.1 \mathrm{M} \mathrm{NaOH}$ solution as electrolyte. This was prepared from Merck p.a. and distilled water. The anodic compartment was magnetically stirred and separated from the cathodic one by the aid of a permselective anionic exchange membrane (IONAC MA-3475). In both compartments, the electrolyte volume was 60 $\mathrm{cm}^{3}$ and the temperature, measured during the experiments, around $20^{\circ} \mathrm{C}$. A Ti plate of $4 \mathrm{~cm}^{2}$ was used as the counter electrode (cathode). The initial concentration of $\mathrm{CN}^{-}$in the anodic compartment was $500 \mathrm{ppm}$ ( $\mathrm{NaCN}$, Merck p.a.). In all electrolytic experiments, a constant current density of $5 \mathrm{~mA} \mathrm{~cm}{ }^{-2}$ was applied and the $\mathrm{CN}^{-}$concentration was determined as a function of time by titration with a $\mathrm{AgNO}_{3}$ standard solution [12]. Additionally, an $\mathrm{Ag} / \mathrm{AgCl} / \mathrm{Cl}^{-}$ (3M) electrode was used as a reference electrode to monitor the potential of the different anodes during electrolysis. It is important to mention that the solution in the cathodic compartment was analyzed at the end and at different stages of the electrolytic treatments to confirm that no cyanide diffused trough the membrane from the anodic compartment.

\subsection{Physico-chemical and electrochemical characterization of spinel electrodes}

All the spinel electrodes were thoroughly characterized by different techniques. To complement electrolytic experiments, the electrocatalytic response of these electrodes for $\mathrm{CN}^{-}$ oxidation was studied by cyclic voltammetry in a conventional three-electrode cell at room temperature. A Pt wire was used as counter electrode, whereas the potentials are referred to a reversible hydrogen electrode (RHE) immersed in the aqueous $0.1 \mathrm{M} \mathrm{NaOH}$ electrolyte solution. In this case, deoxygenated ultrapure water (Purelab Ultra from Elga-Vivendi, 18.2 $\mathrm{M} \Omega$ $\mathrm{cm}$ ) was used to prepare various $\mathrm{CN}^{-}$-containing solutions of different concentrations. The high $\mathrm{pH}$ of these electrolyte solutions $(\mathrm{pH}=13)$ avoided the formation and volatilization of $\mathrm{HCN}$ $(\mathrm{pKa}=9.21)$. The cyclic voltammograms were obtained at a sweep rate of $20 \mathrm{mV} \mathrm{s}^{-1}$.

A scanning electron microscope (Hitachi S-3000N) coupled to a Rontec X-ray detector was used for morphology and composition (energy dispersive X-ray, EDX) microanalysis. The crystalline properties were analyzed by X-ray diffraction measurements in a Seifer JSO-DEBYEFLEX 2002 diffractometer with a Ni-filtered $\mathrm{Cu} K a$ radiation $(\lambda=1.541 \AA)$. The profile intensities were measured by using a step of $2 \theta=0.05^{\circ}$ for a whole time of $3000 \mathrm{~s}$. The lattice cell parameters 
for the cubic spinel crystal system were calculated by using the Bragg's Law, whereas the crystallite size of spinel and Au phases were determined by the Scherrer equation (assuming a shape factor of 0.9 and after subtracting the instrumental line broadening). Deconvolution of (400)- $-\mathrm{CO}_{3} \mathrm{O}_{4}$ from (200)-Au and (440)- $\mathrm{CO}_{3} \mathrm{O}_{4}$ from (220)-Au reflections was performed by using optimized pseudo-Voigt functions. The XPS spectra were registered in a VG-Microtech Multilab electron spectrometer at ultra-high vacuum $\left(5 \cdot 10^{-10} \mathrm{mbar}\right)$ by using the unmonochromatized $\mathrm{Mg} \mathrm{Ka}(1253.6 \mathrm{eV})$ radiation from a twin anode source operated at $300 \mathrm{~W}$. Photoelectrons were collected into a hemispherical analyzer working at $50 \mathrm{eV}$. The binding energy (BE) scale was referenced against the main C1s line of adventitious impurities set at $284.6 \mathrm{eV}$. Peak energies were given to an accuracy of $\pm 0.2 \mathrm{eV}$.

\section{RESULTS}

\subsection{Electrolysis and cyclic voltammetry of alkaline cyanide solution}

Figure 1 shows the performance of various anode materials for the electrochemical removal of cyanide $(500 \mathrm{ppm})$ dissolved in $0.1 \mathrm{M} \mathrm{NaOH}$ at low current density. In Figure 1a, the decrease in cyanide concentration in the course of galvanostatic electrolysis is depicted for representative "active" (pure $\mathrm{Co}_{3} \mathrm{O}_{4}$ spinel) and "non-active" $\left(\mathrm{SnO}_{2}\right.$-based electrodes) metal oxide anodes, as well as graphite and BDD electrodes. The electrocatalytic response for cyanide oxidation is very poor in both "non-active" $\mathrm{SnO}_{2}$-based and "active" pure Co spinel anodes (see the calculated current efficiencies in Table 1). Instead, graphite and BDD anodes exhibit a higher rate of cyanide removal, but they are only capable of eliminating about $49 \%$ to $71 \%$ of cyanide, respectively, within the timescale corresponding to the theoretical charge $\left(Q_{t h}\right)$ necessary to completely transform the target compound to the much less (1000 times) toxic cyanate in a 2-electron reaction $[5,17,18]$ (designated by a vertical dashed line in Fig. 1a). Although, we didn't directly quantify its concentration, it is known that, under the studied alkaline conditions and within the relatively short treatments studied, cyanate is the primary oxidation product from cyanide. The slow conversion rate at all the above anode materials suggests that cyanide is a refractory substrate to electro-oxidation routes involving either highly reactive physisorbed hydroxyl radicals accumulated on the surface of "non-active" anodes at high potential or highly oxidizing metal oxide redox centers formed on "active" anodes by surface oxygen transfer from chemisorbed hydroxyl radicals.
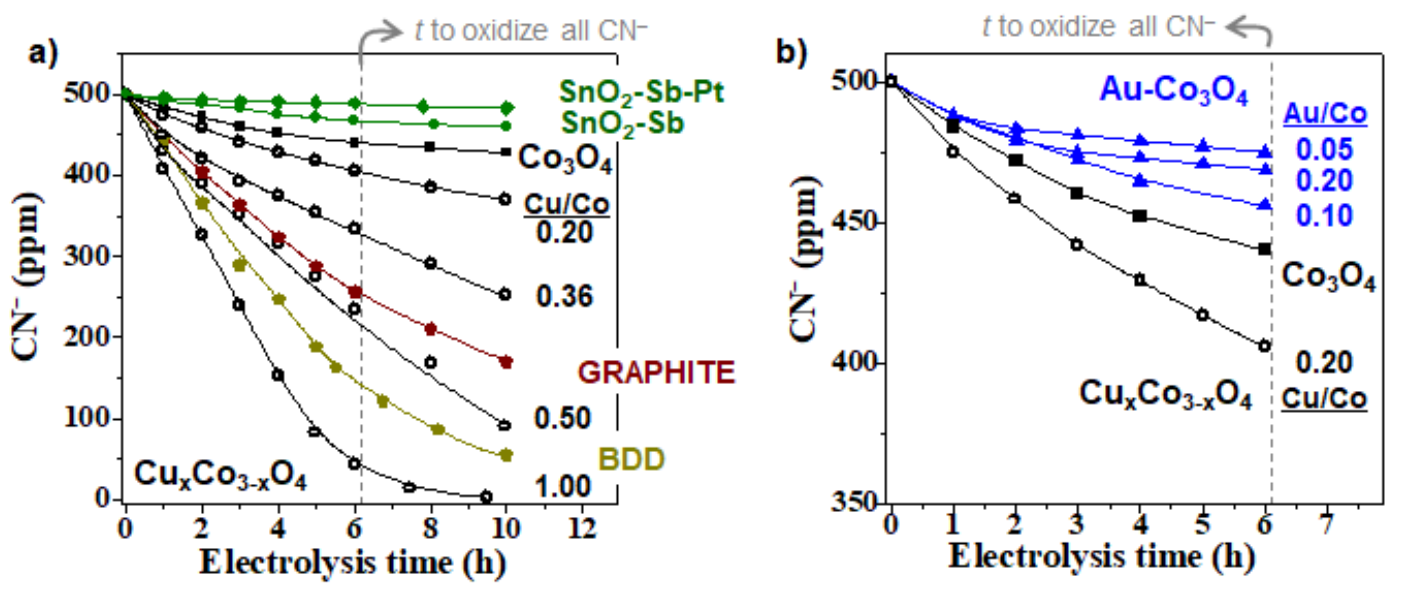

Figure 1. Evolution of the cyanide concentration with the electrolysis time during at $5 \mathrm{~mA} \mathrm{~cm}^{-2}$ by using various types of electrodes in $0.1 \mathrm{M} \mathrm{NaOH}+500$ ppm CN $\mathrm{CN}^{-}$solution: (a) $\mathrm{Cu}_{\mathrm{x}} \mathrm{Co}_{3-\mathrm{x}} \mathrm{O}_{4}$ vs. $\mathrm{CO}_{3} \mathrm{O}_{4}, \mathrm{BDD}$, graphite and $\mathrm{SnO}_{2}$-based anodes; (b) $\mathrm{Au}-\mathrm{CO}_{3} \mathrm{O}_{4}$ vs. $\mathrm{Cu}_{x} \mathrm{CO}_{3-x} \mathrm{O}_{4}$ and $\mathrm{CO}_{3} \mathrm{O}_{4}$. 
Reports by earlier authors pointed out that a remarkable enhancement of cyanide electrooxidation can be achieved by using copper ion species, either dissolved in the bulk solution or as heterogeneous catalysts [18-23]. This effect has been attributed to the interaction of Lewis base cyanide ions with copper ion centers to form either deposited or adsorbed cyanocomplexes $[12,20,21]$. These findings encouraged us to attempt the design and testing of low cost, mixed metal oxide electrocatalysts containing metal ions with strong coordination by cyanide ligand. Thus, a set of mixed $M-C o$ spinel oxides $(M=C u, A u)$ with different doping levels were prepared and used as anodes to electrolyze alkaline cyanide solutions (Fig. 1a-b). In accordance with our previous results obtained in undivided filter-press cell [12], an outstanding promotion of the cyanide removal by electro-oxidation is observed on mixed CuCo spinel electrodes. The catalytic effect rises with the increasing $\mathrm{Cu} / \mathrm{Co}$ ratio, until it levels off at $\mathrm{Cu} / \mathrm{Co} \geq 1$, when the current efficiency for a cyanide-to-cyanate conversion exceeds $90 \%$ (Table 1). This value of current efficiency is unrivaled in the literature dealing with electrochemical removal of cyanide at a variety of electrode materials (Table 1 [24-30]). The similarly high values reported by Hine et al [25] with $\mathrm{PbO}_{2}$ anodes, however, were obtained by using much higher concentrated cyanide solutions (5000-26000 ppm), so they drastically decreased below $65 \%$ with the decrease of the cyanide concentration below 2500 ppm. However, Au-doped Co spinels exhibit a very poor catalytic activity towards cyanide oxidation in the range $\mathrm{Au} / \mathrm{Co}=0.05-0.20$ (Figure $1 \mathrm{~b}$ ). The rate of cyanide removal is even lower than that of the parent pure $\mathrm{Co}$ spinel. By contrast, note that the binary $\mathrm{Cu}-\mathrm{Co}$ oxide with $\mathrm{Cu} / \mathrm{Co}=0.20$ shows a substantially improved oxidation rate when compared to the pure spinel (Figure 1b).

Table 1. Percentage of initial cyanide oxidized after passing the theoretical charge for total 2electron cyanide oxidation $\left(Q_{t h}\right)$, i. e. current efficiency for cyanide oxidation for different anode materials, calculated from the data plotted in Figure 1, and comparison with literature.

\begin{tabular}{|c|c|c|c|c|c|c|c|c|c|c|}
\hline \multicolumn{8}{|c|}{ Electro-oxidized $\mathrm{CN}^{-}(\%)\left(\right.$ at $\left.Q_{t h}\right)=$ Current efficiency (\%) } & \multicolumn{3}{|c|}{ Literature data } \\
\hline \multicolumn{2}{|c|}{$\mathrm{Ti} / \mathrm{Cu}-\mathrm{CO}_{3} \mathrm{O}_{4}$} & $\%$ & \multicolumn{2}{|c|}{$\mathrm{Ti} / \mathrm{Au}-\mathrm{Co}_{3} \mathrm{O}_{4}$} & $\%$ & Other & $\%$ & Anode & $\%$ & Ref. \\
\hline \multirow{5}{*}{$\stackrel{\circlearrowright}{\circlearrowright}$} & 0.07 & 14 & \multirow{5}{*}{$\begin{array}{l}\stackrel{0}{3} \\
\frac{1}{2}\end{array}$} & 0.05 & 5 & Graphite & 49 & Graphite & 1,80 & 24,25 \\
\hline & 0.20 & 18 & & 0.10 & 9 & BDD & 71 & $\mathrm{PbO}_{2}$ & $90-100$ & 25 \\
\hline & 0.36 & 33 & & \multirow{3}{*}{0.20} & \multirow[t]{3}{*}{6} & $\mathrm{CO}_{3} \mathrm{O}_{4}$ & 12 & Stainless steel & 34 & 25 \\
\hline & 0.50 & 53 & & & & $\mathrm{SnO}_{2}-\mathrm{Sb}$ & 6 & $\mathrm{Pt}, \mathrm{Ti} / \mathrm{Pt}$ & $44,<40$ & 25,26 \\
\hline & 1.00 & 92 & & & & $\mathrm{SnO}_{2}-\mathrm{Sb}-\mathrm{Pt}$ & 2 & $\mathrm{Ti} / \mathrm{CO}_{3} \mathrm{O}_{4}$ & 28 & 27 \\
\hline & & & & & & & & BDD & $3-8$ & 28 \\
\hline & & & & & & & & $\mathrm{Ti} / \mathrm{SnO}_{2}-\mathrm{Sb}\left(\mathrm{RuO}_{2}\right)$ & $<1$ & 29 \\
\hline & & & & & & & & $\mathrm{Ti} / 70 \mathrm{TiO}_{2} / 30 \mathrm{RuO}_{2}$ & 37 & 30 \\
\hline
\end{tabular}

It is worthy to mention that we analyzed and found a small amount of metals ( $\mathrm{Co}$ and $\mathrm{Cu}$ ) in the electrolyte solution after the electrolytic experiments. This quantity corresponded to ca. 0.1-1.0 \% of the metallic species in the oxide coatings. These metallic species were also observed after electrolytic studies in the absence of cyanide (attributed to some coating loss before stabilization) and are too low compared to the amount of cyanide removed (see Table S1 in Supporting Info (SI)). Hence, the possibility of any significant effect of metal dissolution and cyanide complexation on the observed rapid cyanide concentration decay for the most active $\mathrm{Cu}$-doped $\mathrm{CO}_{3} \mathrm{O}_{4}$ anodes must be ruled out. On the other hand, it is remarked that the compared electrocatalytic activities are exclusively referred to cyanide removal. Considering that the resulting secondary less-toxic waters constitute a minor problem, a more detailed investigation on the intermediates and final products and the complete purification of the studied waters was not attempted in this work. 
Cyclic voltammograms for cyanide in alkaline solution on selected M-Co mixed oxides support the trends observed in the electrolysis study. Figure 2 shows the first voltammetric scan recorded in cyanide solutions of different concentrations covering the range 10-200 ppm (solid lines). The stabilized voltammogram of each electrode in the background electrolyte is also depicted for the sake of comparison (dashed line). The voltammetric trace on catalytic Cudoped Co oxide electrodes (Fig. 2a-C) shows a cyanide oxidation current in the potential region corresponding to the $\mathrm{Co}(\mathrm{III}) \leftrightarrow \mathrm{Co}$ (IV) surface redox couple $\left(\mathrm{A}_{2} / \mathrm{C}_{2}\right.$ peak in Fig. 2e). At a low $\mathrm{Cu}$ doping level (i.e. $\mathrm{Cu} / \mathrm{Co}=0.2 \mathrm{Fig}$. $2 \mathrm{a}$ ), the oxidation currents in the first scan slightly decrease with the $\mathrm{CN}^{-}$concentration (see the inset of Fig. 2a) and/or with the increasing number of cycles.

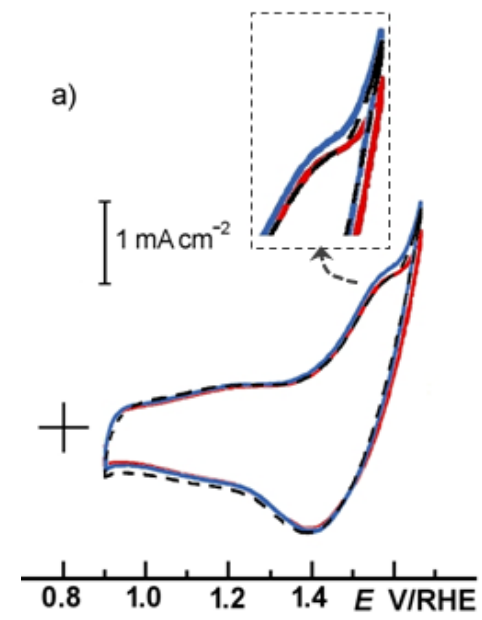

d)
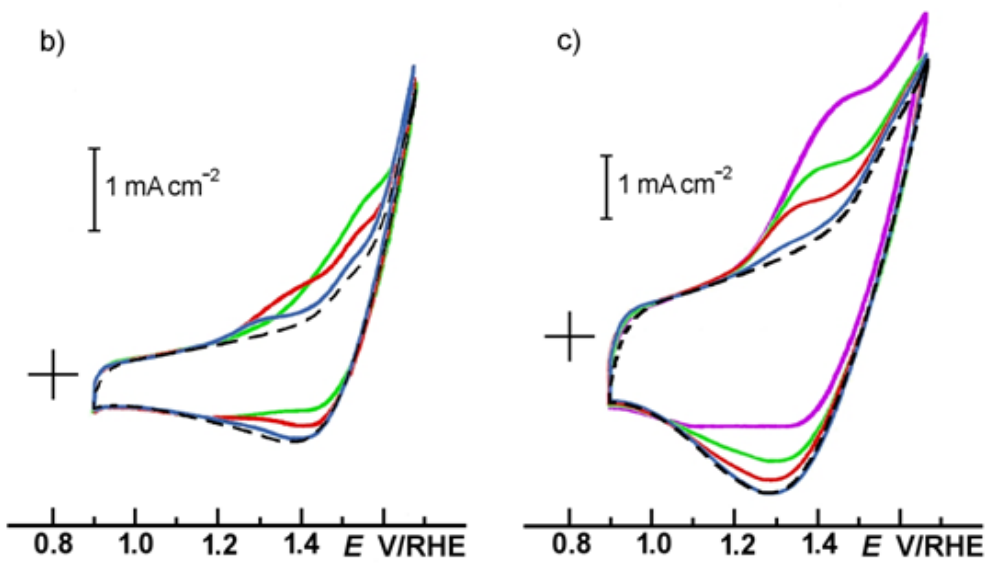

e)
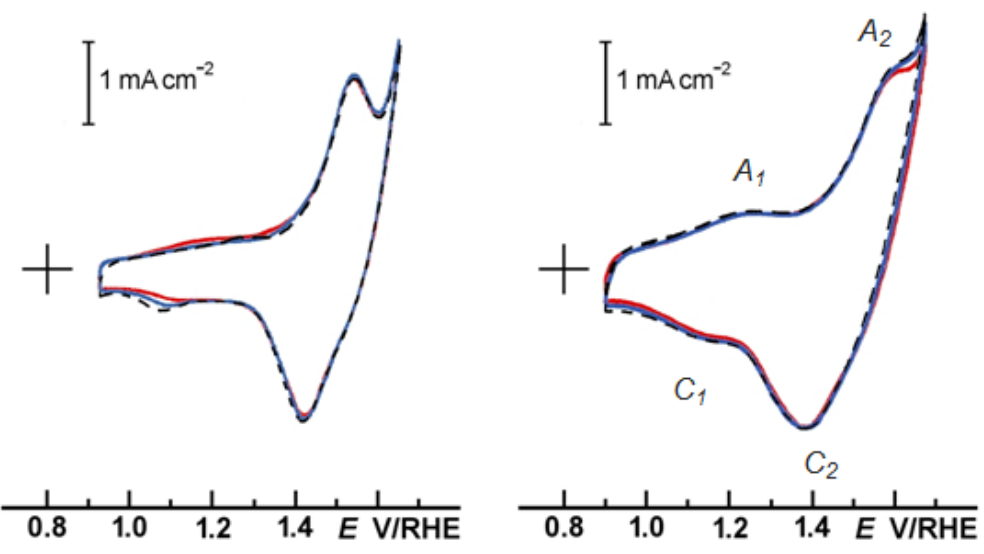

Figure 2. 1st cyclic voltammograms of M-Co mixed oxide electrodes of different doping levels in $0.1 \mathrm{M} \mathrm{NaOH}$ and 0 (dashed line), 10 (blue solid line), $50 \mathrm{ppm}$ (red solid line), 100 (green solid line) and 200 (purple solid line) ppm $\mathrm{CN}^{-}$solutions: (a) $\mathrm{Cu} / \mathrm{Co}=0.2$; (b) $\mathrm{Cu} / \mathrm{Co}=0.36$; (c) $\mathrm{Cu} / \mathrm{Co}$ $=1.00 ;$ (d) $\mathrm{Au} / \mathrm{Co}=0.10$ and (e) pure $\mathrm{Co}_{3} \mathrm{O}_{4}$ spinel. Scan rate $=20 \mathrm{mV} \mathrm{s}^{-1}$.

This voltammetric behavior was explained for pure $\mathrm{CO}_{3} \mathrm{O}_{4}$ in terms of a competing $\mathrm{CN}^{-}$ oxidation with partial surface blockage [13]. However, while the oxidation currents in the first scan are higher (or similar) than that of the blank voltammogram for the Cu-doped spinel (Fig. $2 \mathrm{a}$ ), they remain below that of the blank experiment for pure $\mathrm{Co}_{3} \mathrm{O}_{4}$ (Fig. 2e). This indicates that the presence of $\mathrm{Cu}$ may partially promote the oxidation or alleviate the blocking effect of $\mathrm{CN}^{-}$on the surface of the Co spinel. This effect was confirmed in spinels with a higher $\mathrm{Cu}$ 
content (Fig. 2b-c). For example, for the spinel $\mathrm{Cu} / \mathrm{Co}=0.36$ (Fig. 2b) the oxidation currents during the first cycles gradually increase with the $\mathrm{CN}^{-}$concentration. And for a given concentration, these oxidation currents substantially increase with the amount of dopant $\mathrm{Cu}$ (see the results for $\mathrm{Cu} / \mathrm{Co}=1.00$ in Fig. 2c), involving an outstanding electrocatalytic effect.

On the contrary, the voltammetric response of the oxide with $\mathrm{Au} / \mathrm{Co}=0.10$ (Fig. 2d), which has been found the best among the studied Au-doped $\mathrm{Co}$ oxides, resembles that of pure $\mathrm{CO}_{3} \mathrm{O}_{4}$ (Fig 2e) and no significant cyanide oxidation current can be discerned independently of the $\mathrm{CN}^{-}$ concentration. In fact, the only distinctive feature in the CV of Au-doped anodes in cyanide solution is the partial loss of the cathodic peak at $1.1 \mathrm{~V} / \mathrm{RHE}$, which is more significant as the cyanide concentration is raised. This peak can be assigned to the reduction of gold surface oxides. The loss of this peak might be associated with a strong adsorption of cyanide on gold that hampers the onset of gold surface oxides, very much like it occurs on smooth gold metal electrodes (see Fig. $\mathrm{S} 1$ in $\mathrm{SI}$ ). The close similarity in the voltammetric behavior exhibited by mixed Au-Co oxides with $\mathrm{Au} / \mathrm{Co}=0.10$ and $\mathrm{CO}_{3} \mathrm{O}_{4}$ (Fig. 2d-e) is consistent with their similar current efficiency in the bulk electrolysis of alkaline cyanide solutions (Table 2).

Because cyanide shows comparable affinity to d-filled transition metals, like coinage metals [31], other aspects related to the microstructure, crystalline properties and true bulk/surface chemical composition of the $\mathrm{M}-\mathrm{Co}(\mathrm{M}=\mathrm{Cu}, \mathrm{Au})$ oxide coatings must be considered to understand their drastically different catalytic activity. Therefore, results of materials characterization by using SEM, dispersive X-ray microanalysis, XRD and XPS are presented and discussed below.

\subsection{Physicochemical characterization}

\subsubsection{Surface microstructure}

Figure 3 shows high magnification SEM micrographs of pure cobalt spinel films and $\mathrm{Cu}$ - or AuCo mixed oxides with different amounts of the foreign metal ion dopant. The compact and smooth surface with some submicrometric cracks of $\mathrm{CO}_{3} \mathrm{O}_{4}$ (Fig. 3f) is preserved at low $\mathrm{Cu}$ doped Co oxide films (Fig. 3a-b), although some isolated macrodefects are distinguished and small nanosized pinholes are distributed all over the surface. Upon increasing the amount of $\mathrm{Cu}$, the surface texture gradually roughens and becomes more porous [14]. When the $\mathrm{Cu} / \mathrm{Co}$ ratio exceeds 0.5 (i.e. that for the stoichiometric copper cobaltite), the surface reaches a granular and highly porous nature (Fig. 3c). This drastic change in the topology was ascribed to the segregation of a surface $\mathrm{CuO}$ phase [14]. At low magnification (see SI, Fig. S2), the surface aspect of Au-Co mixed oxide films resembles that of binary $\mathrm{Cu}$-Co oxide coatings of similar metal doping level. However, in high magnification micrographs one can discern the occurrence of bright spots of globular appearance spreading all over the surface (Fig 3d-e). The number of such quasi-spherical features increases with the increasing $\mathrm{Au} / \mathrm{Co}$ ratio, but their size decreases from micrometric to nanometric. 
a) $\mathrm{Cu} / \mathrm{Co}=0.07$
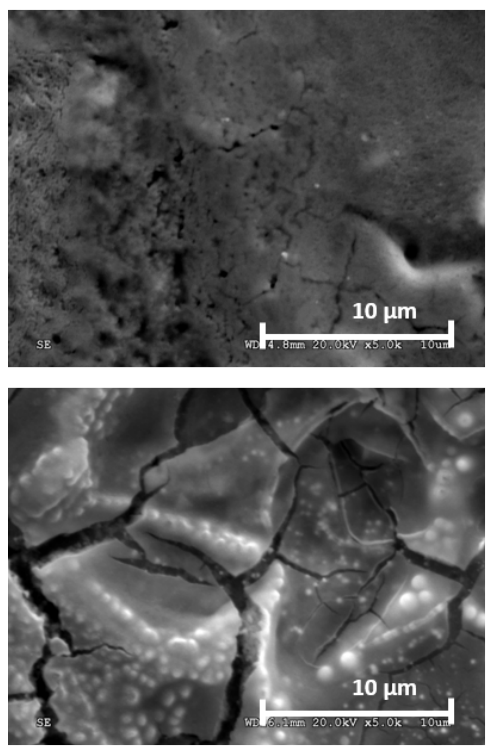

d) $\mathrm{Au} / \mathrm{Co}=0.05$ b) $\mathrm{Cu} / \mathrm{Co}=0.2$
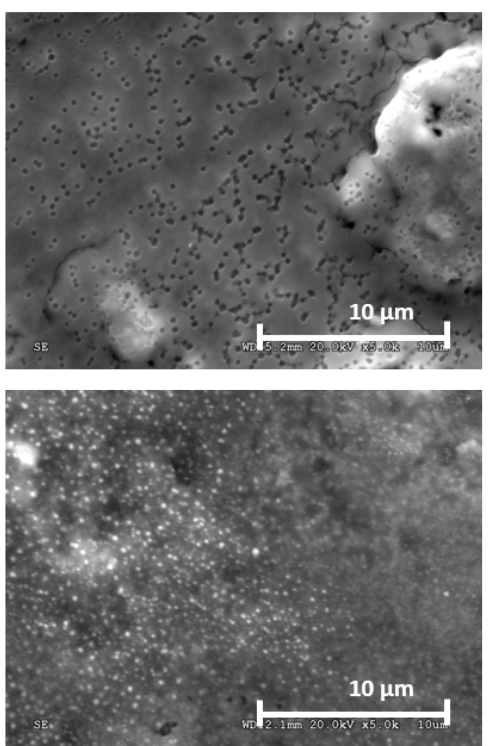

e) $\mathrm{Au} / \mathrm{Co}=0.2$ c) $\mathrm{Cu} / \mathrm{Co}=1.0$
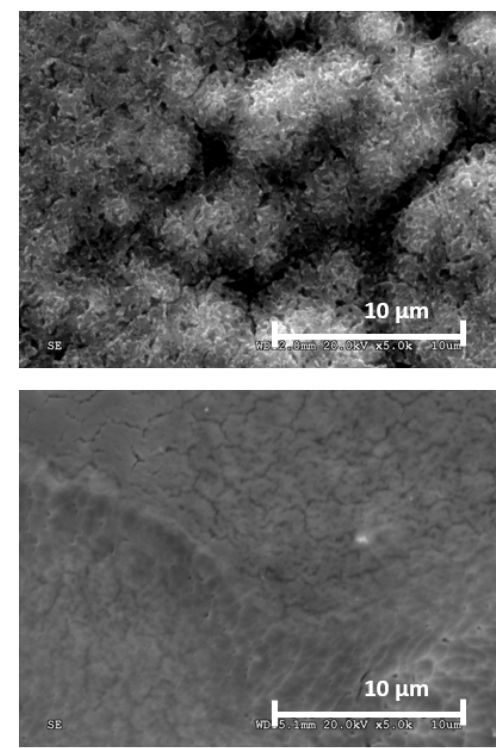

f) $\mathrm{CO}_{3} \mathrm{O}_{4}$

Figure 3. Secondary electron SEM micrographs of Co spinel oxide and mixed $\mathrm{M}$-Co oxide films $(\mathrm{M}=\mathrm{Cu}, \mathrm{Au})$ deposited on $\mathrm{Ti}$ by thermal decomposition (x5000 magnification). Mixed $\mathrm{Cu}-\mathrm{Co}$ spinel oxide with (a) $\mathrm{Cu} / \mathrm{Co}=0.07$, (b) $\mathrm{Cu} / \mathrm{Co}=0.2$, (c) $\mathrm{Cu} / \mathrm{Co}=1.0$; mixed Au-Co oxide with (d) $\mathrm{Au} / \mathrm{Co}=0.05$, (e) $\mathrm{Au} / \mathrm{Co}=0.2$ and (f) pure $\mathrm{Co}_{3} \mathrm{O}_{4}$ spinel.

Backscattered electron images of Au-Co oxide coatings (Fig. 4) confirm the existence of welldispersed globules of increasing number and decreasing size as the nominal $\mathrm{Au} / \mathrm{Co}$ rises. Bright backscattering spots indicate an accumulation of heavier Au atoms and suggest that gold metal ions are not incorporated in the Co spinel lattice, contrary to what it has been reported for $\mathrm{Cu}$ Co spinel oxides of formula $\mathrm{Cu}_{x} \mathrm{Co}_{3-x} \mathrm{O}_{4}[14,32,33]$. Instead, metal ions seem to be converted in segregated Au-rich particles by thermal treatment. Further, the number of gold-containing particles per unit area is much higher in backscattering micrographs than in secondary electron micrographs, which evidences that gold particles occur also at subsurface levels.

a) $\mathrm{Au} / \mathrm{Co}=0.05$

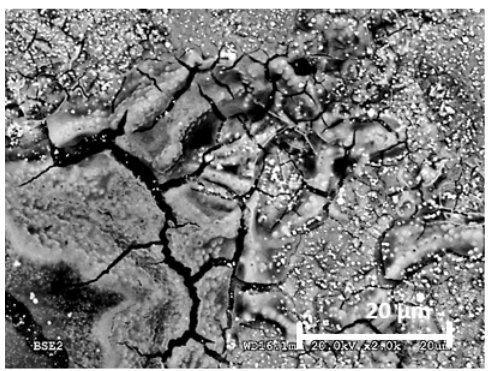

b) $\mathrm{Au} / \mathrm{Co}=0.1$

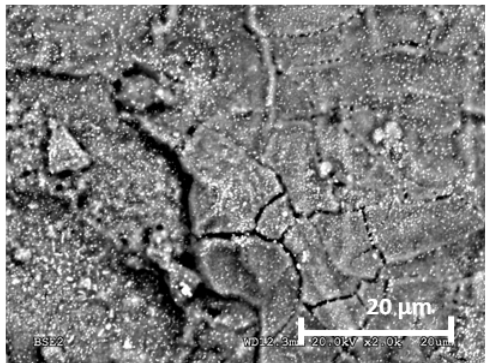

c) $\mathrm{Au} / \mathrm{Co}=0.2$

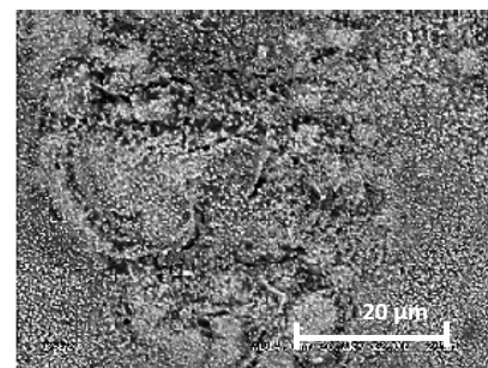

Figure 4. Backscattered electron SEM micrographs of mixed Au-Co oxide thin films deposited on Ti by thermal decomposition (x2000 magnification) with (a) $\mathrm{Au} / \mathrm{Co}=0.05$, (b) $\mathrm{Au} / \mathrm{Co}=0.1$ and (c) $\mathrm{Au} / \mathrm{Co}=0.2$.

\subsubsection{Chemical composition and crystal structure}

The elemental composition of the bulk of mixed M-Co oxide films was measured by EDX microanalysis and compared with the expected nominal composition in Table 2. With the exception of the lowest ratio, the experimental $\mathrm{Cu} / \mathrm{Co}$ ratio in Cu-Co binary oxides is in fairly good agreement with the nominal one up to the composition of the saturated copper cobaltite 
$\left(\mathrm{Cu} / \mathrm{Co}=0.5, \mathrm{CuCO}_{2} \mathrm{O}_{4}\right)$. At a higher $\mathrm{Cu}$ content, a thin surface CuO-like phase is reported to segregate and the experimental bulk composition remains close to that of the saturated spinel [14]. By contrast, the experimental $\mathrm{Au} / \mathrm{Co}$ ratio lies below the nominal value at all doping levels, probably as a consequence of a lower thermal conversion efficiency of the gold precursor salt at the employed pyrolysis temperature. In all cases, the amount of Ti within the sampled layer remains below or close to $1 \%$, thereby suggesting that the average film thickness is of the order of the sampling depth of X-rays in EDX (above $1 \mu \mathrm{m}$ ). Specifically, from the mean value of oxide loadings $\left(3.25 \mathrm{mg} \mathrm{cm}^{-2}\right)$ deposited in this work and the density of $\mathrm{Co}_{3} \mathrm{O}_{4}\left(6.06 \mathrm{~g} \mathrm{~cm}^{-3}\right)$ [34], the coating thickness can be calculated as ca. $5 \mu \mathrm{m}$.

Table 2. Chemical composition and crystal structure of binary $M$-Co spinel oxide films $(M=C u$, $\mathrm{Au}$ ) deposited on Ti by thermal decomposition

\begin{tabular}{|c|c|c|c|c|c|c|c|}
\hline & \multirow{2}{*}{\multicolumn{3}{|c|}{$\begin{array}{c}\text { Bulk (EDX) and surface (XPS) } \\
\text { composition } \\
\text { Atomic ratio } \\
\end{array}$}} & \multicolumn{4}{|c|}{ Crystalline structure (XRD) } \\
\hline & & & & \multicolumn{2}{|c|}{$\begin{array}{l}\text { Spinel lattice } \\
\text { parameters }\end{array}$} & \multicolumn{2}{|c|}{ Crystallite size } \\
\hline & $\begin{array}{c}\text { Nominal } \\
\mathrm{Cu} / \mathrm{Co}\end{array}$ & $\begin{array}{c}\text { EDX } \\
\mathrm{Cu} / \mathrm{Co}\end{array}$ & $\begin{array}{c}\text { XPS } \\
\mathrm{Cu} / \mathrm{Co}\end{array}$ & $a(\AA)$ & $\mathrm{V}\left(\AA^{3}\right)$ & $\begin{array}{l}\text { Spinel }{ }^{a} \\
d(\AA)\end{array}$ & \\
\hline $\mathrm{CO}_{3} \mathrm{O}_{4}$ & --- & --- & --- & 8.084 & 528.29 & 99 & \\
\hline \multirow{6}{*}{$\begin{array}{l}\frac{0}{d} \\
\frac{0}{0} \\
\frac{0}{0} \\
\frac{1}{J} \\
\end{array}$} & 0.07 & 0.04 & 0.11 & 8.093 & 530.06 & 94 & \\
\hline & 0.20 & 0.19 & 0.35 & 8.112 & 533.80 & 81 & \\
\hline & 0.36 & 0.37 & 0.78 & 8.128 & 536.97 & 58 & \\
\hline & 0.50 & 0.51 & 0.78 & 8.130 & 537.36 & 38 & \\
\hline & 1.00 & 0.56 & 6.12 & 8.134 & 538.16 & 45 & \\
\hline & $\begin{array}{c}\text { Nominal } \\
\mathrm{Au} / \mathrm{Co}\end{array}$ & $\begin{array}{c}\text { EDX } \\
\mathrm{Au} / \mathrm{Co}\end{array}$ & $\begin{array}{c}\text { XPS } \\
\mathrm{Au} / \mathrm{Co}\end{array}$ & $a(\AA)$ & $\mathrm{V}\left(\AA^{3}\right)$ & $\begin{array}{c}\text { Spinel }^{a} \\
d(\AA)\end{array}$ & $\begin{array}{l}\mathrm{Au}^{\mathrm{b}} \\
d(\AA)\end{array}$ \\
\hline \multirow{3}{*}{ 立 } & 0.05 & 0.03 & 0.003 & 8.084 & 528.37 & 123 & 310 \\
\hline & 0.10 & 0.06 & 0.01 & 8.082 & 527.91 & 137 & 207 \\
\hline & 0.20 & 0.16 & 0.09 & 8.079 & 527.25 & 138 & 182 \\
\hline
\end{tabular}

a Calculated average value from 220,311, 400, 511 and 440 reflections of $\mathrm{CO}_{3} \mathrm{O}_{4}$.

${ }^{b}$ Calculated average value from 200, 220 and 311 reflections of $A u$.

The X-ray diffraction patterns of the binary spinel oxide films supported on Ti are stacked in Figure 5 and compared to that of pure cobalt spinel and the Ti substrate. Also depicted are the standard powder patterns of $\mathrm{CO}_{3} \mathrm{O}_{4}$ and metallic Au from JPCDS-ICCD files. The diffractograms of low $\mathrm{Cu} / \mathrm{Co}$ mixed spinels show diffraction lines comparable to those of the pure $\mathrm{CO}_{3} \mathrm{O}_{4}$ film, with reflections at $2 \theta=31.29,36.88,44.84,59.40$, and $65.29^{\circ}$ [13], and no peaks attributable to distinct $\mathrm{Cu}$ metal or $\mathrm{Cu}$ oxide phases. These Bragg's angles can be indexed to a cubic spinel lattice belonging to the Fd3m space group, in agreement with data from JPCDS-ICCD file no.9418 (pure spinel phase). Extra lines match with reflections at (002) and (103) planes from the underlying Ti support. Similar diffraction patterns have also been reported for binary Cu-Co oxides with high $\mathrm{Cu} / \mathrm{Co}(0.5-1.5)$ deposited onto Ti by thermal decomposition [14,32,35]. Therefore, it appears clear that these binary $\mathrm{Cu}$-Co oxide films are in the form of a substitutional solid solution phase $\left(\mathrm{Cu}_{x} \mathrm{CO}_{3-\mathrm{x}} \mathrm{O}_{4}\right)$, where copper metal ions are filling sites in the spinel metal ion sublattice. Since no peaks of $\mathrm{CuO}$ phase are observed by XRD for the $\mathrm{Cu} / \mathrm{Co}=$ 1.00 , the segregation of this phase may occur only at the top surface of this anode. Then, the surface segregation is evidenced by the comparison between XPS and EDX analysis in Table 2. As a result of $\mathrm{Cu}$ doping, the mean unit cell size is observed to increase continuously (Table 2), which was explained by the substitution of $\mathrm{Co}$ (II) by higher ionic radius $\mathrm{CU}$ (II) at octahedral and tetrahedral sites [14]. 


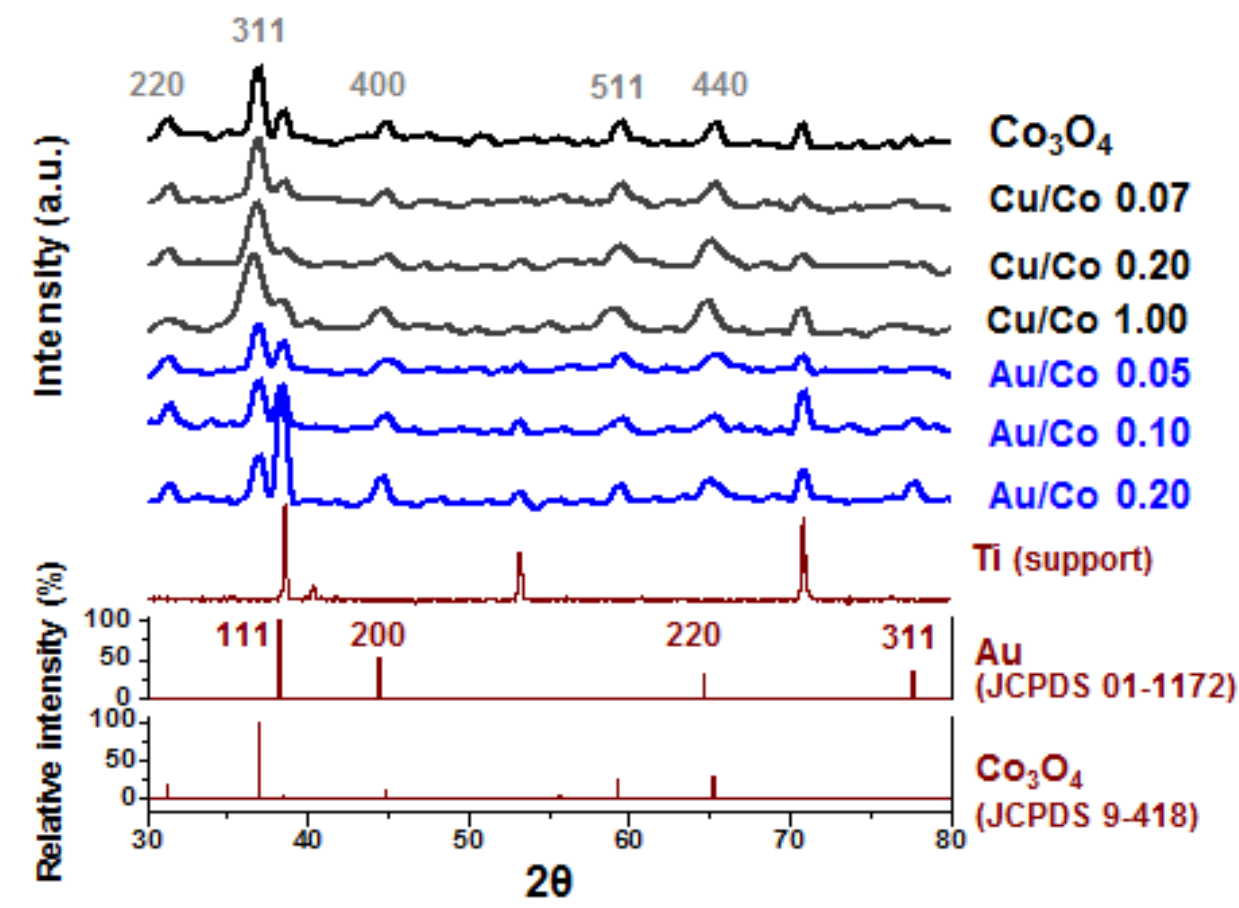

Figure 5. X-Ray diffraction patterns of $\mathrm{Co}$ spinel oxide and mixed $M$-Co oxide films ( $M=\mathrm{Cu}, \mathrm{Au}$ ) deposited on Ti by thermal decomposition.

In contrast, the diffraction patterns of mixed Au-Co oxide films can be described as a superimposition of the diffractograms of pure $\mathrm{CO}_{3} \mathrm{O}_{4}$ and a segregated $\mathrm{Au}$ metal crystalline phase. The diffraction peaks of $\mathrm{Au}$ are observed at angles $2 \theta=38.22$ and $77.64^{\circ}$, indexed to reflections at the crystallographic planes (111) and (311) of a pure fcc metal lattice, in accordance with the powder standard pattern of metallic gold (JCPDS-ICCD 01-1172). The main (111) diffraction is partly overlapped with the signal from Ti (002). The Au reflections at planes (200) and (220) are barely distinguished because of their strong overlapping with cobalt spinel oxide lines at planes (400) and (440) respectively. Interestingly, the relative intensity of the gold lattice main reflections (111) and (311) with respect to the spinel most intense (311) line increases with the increasing $\mathrm{Au} / \mathrm{Co}$ ratio. The same trend was observed for the (200) and (220) reflections after deconvolution (see an example in SI, Fig. S3). Furthermore, the lattice parameters of the spinel phase are practically unaffected by the presence of Au (Table 2), which further support that the mixed oxide film consists of a mixture of a pure Co spinel phase and a segregated Au metal phase.

The calculated crystallite sizes of spinel and $\mathrm{Au}$ phases for pure and $\mathrm{M}$-doped $\mathrm{CO}_{3} \mathrm{O}_{4}$ are collected in Table 2. In the case of $\mathrm{Cu}$-doped $\mathrm{CO}_{3} \mathrm{O}_{4}$, the spinel crystallite size decreases upon substitution of $\mathrm{Co}(\mathrm{II})$ by $\mathrm{Cu}(\mathrm{II})$ in the solid solution phase $\left(\mathrm{Cu}_{\mathrm{x}} \mathrm{CO}_{3-\mathrm{x}} \mathrm{O}_{4}\right)$ [14]. On the contrary, the mean crystallite diameter of the spinel phase in Au-doped $\mathrm{CO}_{3} \mathrm{O}_{4}$ is considerably higher than that of pure $\mathrm{CO}_{3} \mathrm{O}_{4}$, and it slightly increases with the Au content. Considering that the crystallite size is greatly affected by the temperature and time of the thermal treatment, this observed spinel size-increase could be assigned to "over temperatures" produced around Au nano and micro particles. On the other hand, the dimensions of $\mathrm{Au}$ crystallites decrease with the $\mathrm{Au}$ content, what is line with the particle size reduction observed by SEM (Fig. 3 and 4).

The surface composition of the oxide films was thoroughly investigated by XPS. The detailed spectra of the Co2p core level is not affected by the presence of dopant metal species in the 
mixed $\mathrm{Cu}$ - or Au-Co oxides (Figure 6a). All spectra show the typical features of a pure $\mathrm{Co}_{3} \mathrm{O}_{4}$ crystal with spinel structure: a main spin-orbit doublet with a $15.1 \mathrm{eV}$ binding energy gap, formed by two broad and asymmetric core-level photoemission peaks, and a low intensity shake-up satellite characteristic of paramagnetic Co(II) high-spin complexes shifted by $9.5 \mathrm{eV}$ above the main $\mathrm{Co}_{2} \mathrm{p}_{3 / 2}$ transition $(\sim 780.0 \mathrm{eV}, \mathrm{fwhm}=3.1 \mathrm{eV})$. This result means that the local coordination environment of $\mathrm{Co}$ ions in the spinel lattice is not distorted by neither $\mathrm{Cu}(\mathrm{II})$ ions entering the crystal structure nor by segregated gold particles. Therefore, it suggests a weak interaction between the foreign metal dopants and spinel Co ions in the mixed oxides.
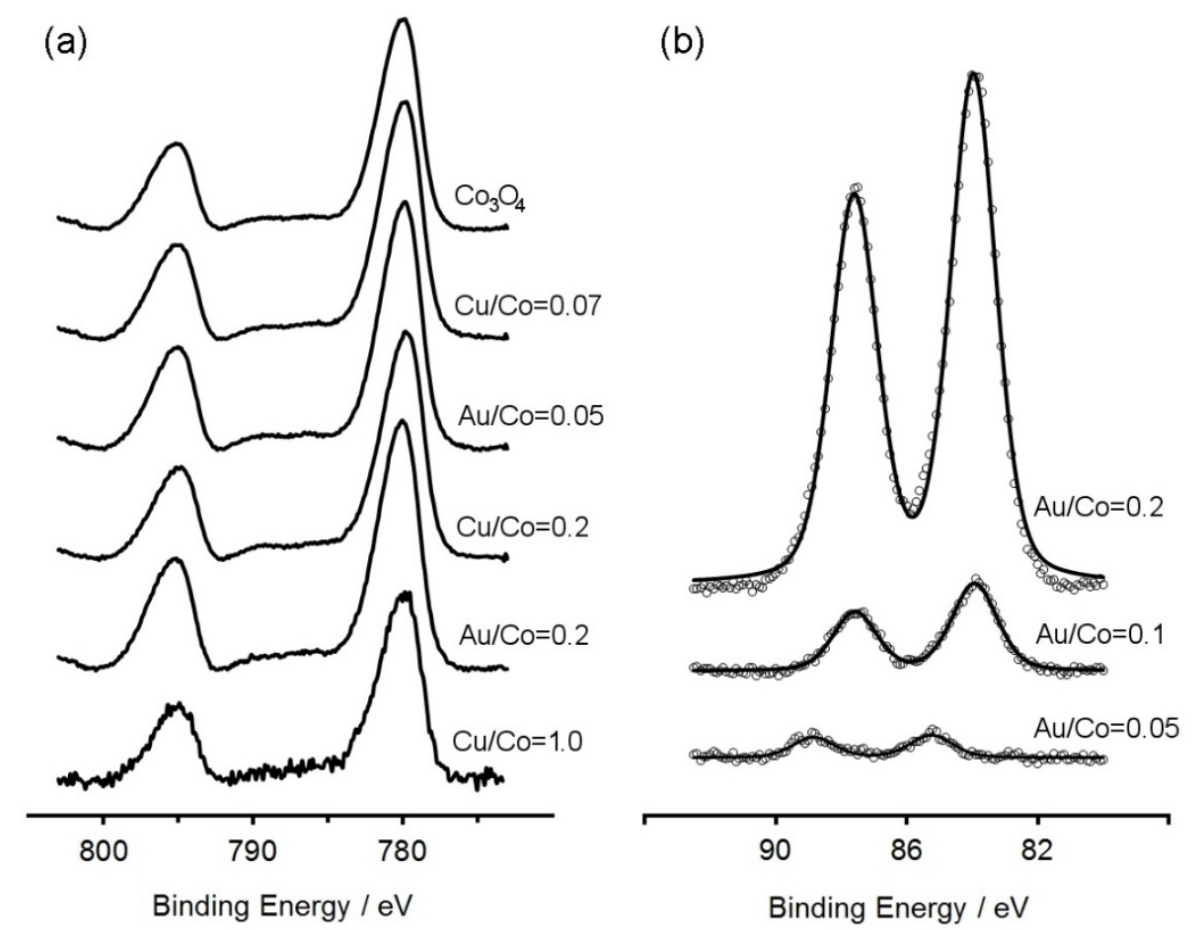

Figure 6. High resolution X-Ray photoelectron spectra of mixed $\mathrm{Cu}$ - and Au-Co oxide thin films deposited on Ti: (a) Co $2 p$ core-level, (b) Au $4 f$ core level.

As to the $\mathrm{Au} 4 \mathrm{f}$ detailed spectrum in Au-Co mixed oxide films, Figure $6 \mathrm{~b}$ shows a doublet with the $4 \mathrm{f}_{7 / 2}$ core-level electron photoemission located at about $84.0 \pm 0.2 \mathrm{eV}$ and a linewidth corresponding to a single atomic environment when the nominal $\mathrm{Au} / \mathrm{Co} \geq 0.10$. However, the principal $4 \mathrm{f}_{7 / 2}$ peak is shifted to higher binding energies $(85.2 \pm 0.2 \mathrm{eV})$ at very low Au doping levels. It is then confirmed that the segregated Au-rich phase is in their metallic state [36], at least at the higher $\mathrm{Au} / \mathrm{Co}$ ratios, while it probably crystallizes in the form of a $\mathrm{Au}(\mathrm{I})$ oxide phase at the lowest ratio. In all cases, the surface relative abundance of $\mathrm{Au}$ is lower than the nominal composition of the precursor salt (Table 2). Moreover, this foreign metal is even more depleted at the surface than in the bulk of the mixed oxide film.

\section{DISCUSSION}

The wide disparity in cyanide removal performance shown by the reference "active" and "nonactive" anode materials in Fig. 1 points to a low inherent catalytic activity of surface sites involving either a mere accumulation of intermediate physisorbed hydroxyl radicals ("nonactive" anodes) or reversible metal oxide redox centers acting as oxidation heterogeneous mediators ("active" anodes). 
In the particular case of the pure $\mathrm{CO}_{3} \mathrm{O}_{4}$ anode, $\mathrm{CVs}$ in Fig $2 \mathrm{e}$ demonstrate that the cyanide oxidation mediated by $\mathrm{Co}(\mathrm{IV})$ surface species within the potential window of the $A_{2} / C_{2}$ redox wave, according to the simplified reaction scheme described by Eq.(1)-(2), is rather inefficient, and surface Co(IV) species are preferentially converted back to Co(III) with oxygen evolution, Eq. (3). This view is in agreement with the sluggish performance of such an electrode in electrolysis runs.

$$
\begin{gathered}
\mathrm{CoOOH}+\mathrm{OH}^{-} \rightarrow \mathrm{H}_{2} \mathrm{O}+\mathrm{CoO}_{2}+e^{-} \\
\mathrm{CN}^{-}+2 \mathrm{CoO}_{2} \rightarrow \mathrm{CNO}^{-}+2 \mathrm{CoOOH} \\
2 \mathrm{CoO}_{2}+\mathrm{OH}^{-} \rightarrow 2 \mathrm{CoOOH}+\mathrm{O}_{2}+2 e^{-}
\end{gathered}
$$

However, the incorporation of copper divalent ions in Co spinel thin films has shown to yield an "active" spinel structure with enhanced catalytic activity for cyanide oxidation. Thus, the cyanide conversion efficiency in bulk electrolyses is largely increased with the increasing $\mathrm{Cu}$ content in the mixed spinel, until its effect seems to stabilize at $\mathrm{Cu} / \mathrm{Co}$ ratios close to or above 1.0 (Fig. 1). Cyclic voltammograms (Fig. 2a-c) reveal that the electro-oxidation of cyanide occurs within the potential range involving the reversible surface redox transition $\mathrm{Co}(\mathrm{III}) \rightarrow \mathrm{Co}(\mathrm{IV})$, designated as $\mathrm{A}_{2}$ wave, with loss in the charge under its cathodic counterpart, $\mathrm{C}_{2}$. As the amount of divalent copper ions incorporated into the spinel lattice is raised, the cyanide oxidation current increases in parallel. The onset of cyanide oxidation process is even shifted to lower potentials at $\mathrm{Cu} / \mathrm{Co}$ approaching that of the stoichiometric $\mathrm{CuCO}_{2} \mathrm{O}_{4}$ and beyond (Fig. $2 \mathrm{~b}$ and $2 \mathrm{c}$ ). Simultaneously, the cathodic wave $\mathrm{C}_{2}$ corresponding to the reduction of highly oxidized metal ion states at the surface (e.g. Co(IV) $\rightarrow \mathrm{Co}(\mathrm{III})$ ) is fully suppressed provided that the cyanide concentration is sufficiently high. These features are commonly regarded as diagnostic proof of the participation of redox metal ion centers as electron transfer mediators $[13,27]$. Nevertheless, the true role of copper ion species as catalysts for the cyanide oxidation is the subject of some controversy. Some authors proposed that the reaction is catalyzed by intermediate adsorbed copper-cyano complexes involving $\mathrm{Cu}(\mathrm{II}) / \mathrm{Cu}(\mathrm{I})$ states [19-21,37,38]. Others attributed the catalytic effect to the inherent oxidizing power of heterogeneous redox $\mathrm{Cu}(\mathrm{II}) / \mathrm{Cu}(\mathrm{III})$ mediators in electrodeposited $\mathrm{CuO}$ films, without considering any specific metal-cyanide interaction [20]. Wels and Johnson [22] postulated that active $\mathrm{Cu}(\mathrm{III})$ in the surface lattice of copper oxide films may function as both adsorption sites for cyanide and hydroxyl radicals generated by anodic discharge of water. Then, intermediate adsorbed $\mathrm{HO}^{*}$ was believed to be responsible of the oxidation of adsorbed cyanide through an oxygen transfer mediated mechanism. In the case of $\mathrm{Cu}_{x} \mathrm{CO}_{3-\mathrm{x}} \mathrm{O}_{4}$ electrodes, the participation of adsorbed hydroxyl radicals as the prevalent oxidant species seems doubtful because cyanide oxidation takes place at potentials well below the onset of the OER (Fig. 2a-c). In a recent in situ Raman study [12], we demonstrated that cyanide binds lattice divalent copper ions, probably in the form of copper-cyano complexes, $\mathrm{Cu}_{\text {(spinel) }}-\left(\mathrm{CN}^{-}\right)_{x}$, at the surface of $\mathrm{Cu}_{x} \mathrm{CO}_{3-\mathrm{x}} \mathrm{O}_{4}$ films. It was also shown that these surface complexes are oxidized and removed within the potential window where cyanide oxidation current arises. Therefore, we put forward a mechanism involving pre-adsorption of cyanide at $\mathrm{Cu}(\mathrm{II})$ sites and its reaction with oxidized electron transfer mediators formed at neighbouring sites, as soon as they are generated at sufficiently high electrode potential. It still remains unclear whether electron mediation at adjacent sites is done exclusively by $\mathrm{Co}(\mathrm{III}) / \mathrm{Co}$ (IV) redox metal centers or also by $\mathrm{Cu}$ (II)/Cu(III) surface couples. 
The notable success of Cu-doped Co oxide as cyanide oxidation electrocatalysts prompted us to use mixed oxides synthesized by adding salts of other metal ions possessing well-known $\mathrm{d}$ coordination chemistry with cyanide ligands (eg. Au, Pt [31]) to the precursor solution. However, the results reported in this work evidence that the mere inclusion in the oxide composition of transition metal atoms with high affinity to cyanide ligands does not ensure high catalytic activity for the electro-oxidation of cyanide. In fact, both Pt-doped $\mathrm{SnO}_{2}-\mathrm{Sb}$ anodes and mixed Au-Co oxides turn out to be poor electrocatalysts for cyanide anodic oxidation, with a response comparable to their parent pure oxide phase (Fig. 1). The exhaustive materials characterization study of these oxide films reveals that Au salt precursors are thermally decomposed to yield metal gold micro- and nanoparticles finely dispersed within the host Co spinel phase. In a similar way, XRD studies allowed the identification of a segregated metal Pt phase coexisting with the principal rutile metal oxide matrix in Pt-doped $\mathrm{SnO}_{2}$-Sb anodes formed by calcination from their respective solution precursors [39]. In the same work, Fourier-Transform EXAFS spectra of the Pt- $\mathrm{L}_{\| I}$ edge confirmed that the local environment around Pt atoms in the oxide film is the same than that in metallic polycrystalline Pt.

The adsorption of cyanide on metal electrodes was the subject of intensive fundamental insight in the past 80 s and 90s. Cyanide ion is known to form stable adsorbed layers with strong metal-ligand interaction at many pure transition metal electrodes, including $\mathrm{Zn}, \mathrm{Ni}, \mathrm{Cu}$, $\mathrm{Ag}, \mathrm{Au}, \mathrm{Pt}$ and Pd [40-45]. Despite the nature of the metal-cyanide bonding is somewhat controversial (eg. it has been described by different quantum mechanics calculation methods either as ionic in character $[43,46]$ or as a result of ligand $\sigma$-donation to empty metal bonding orbitals [47]), there is a general consensus that the strength of the surface bond dictates the inhibition and sluggish kinetics of the electrochemical oxidation of free cyanide $[23,26,48]$. Then, it seems reasonable that $\mathrm{Au}$ - or Pt-rich particles do not contribute to any significant enhancement of the catalytic activity of Co or Sn oxide anodes towards the electro-oxidation of free cyanide. As possible reasons, on the one hand, strongly bound cyanide hampers facile solution cyanide oxidation at noble metal particles. On the other hand, sites for cyanide binding on noble metal surfaces are not made easily accessible to active sites on the principal metal oxide matrix (either surface redox electron mediators in Co spinel oxides or anodic Otransfer reaction sites in $\mathrm{SnO}_{2}$-based oxides), because they all belong to independent, segregated phase domains. Therefore, the oxidation of free cyanide through the mechanism proposed for true Cu-Co solid solution spinel films is most likely to be hindered in segregated noble metal-doped oxides.

The marked differences in the electrocatalytic response of $\mathrm{Cu}$ - and Au-doped $\mathrm{Co}_{3} \mathrm{O}_{4}$ emphasizes the significance of the anode design for its application in wastewater treatment. The comparative study presented in this work demonstrates that the electrocatalytic activity for $\mathrm{CN}^{-}$electro-oxidation of binary Cu-Co spinels with $0.5<\mathrm{Cu} / \mathrm{Co} \leq 1.0$ is much better than that of various reference materials, included BDD. In addition, these spinel anodes show good electrochemical stability $[14,15]$. Hence, a major consequence of this investigation is that a stable anode, made of widely available economically-priced components, can be used for water decontamination with very high current efficiency (more than $90 \%$ ).

\section{CONCLUSIONS}

Binary Cu-Co spinels with $0.5<\mathrm{Cu} / \mathrm{Co} \leq 1.0$, showing a remarkable "active" character and activity for the OER, have been found to exhibit similar or even higher activity for $\mathrm{CN}^{-}$electrooxidation than the most powerful "non-active" BDD anode. The conversion rate of cyanide 
remarkably increases as the amount of $\mathrm{Cu}$ is raised, so that spinels with $\mathrm{Cu} / \mathrm{Co}=1$ are by far the best electrocatalysts among all the tested materials in this work, at least for cyanide detoxification. By contrast, the doping of $\mathrm{Co}$ spinel oxide films with Au does not bring about any kinetic improvement with respect to the parent pure $\mathrm{CO}_{3} \mathrm{O}_{4}$ spinel.

These marked differences on electroactivity between $\mathrm{Cu}$ - and $\mathrm{Au}$-doped $\mathrm{CO}_{3} \mathrm{O}_{4}$ spinels have been reasonably justified by the distinct physico-chemical properties of both mixed oxides. Thus, whereas $\mathrm{Cu}$ doping leads to a monophasic $\mathrm{Cu}$-substituted cobaltite spinel $\left(\mathrm{Cu}_{x} \mathrm{CO}_{3-\mathrm{x}} \mathrm{O}_{4}, 0<\right.$ $x \leq 1.0$ ), mixed Au-Co oxide films do not form solid oxide solutions even at very low metal doping ( $\mathrm{Au} / \mathrm{Co} \leq 0.2$ ). Instead, these materials are composed of well-dispersed Au metal nanoor micro-particles within the principal $\mathrm{CO}_{3} \mathrm{O}_{4}$ phase $\left(\mathrm{Au}-\mathrm{CO}_{3} \mathrm{O}_{4}\right)$. The high catalytic response of $\mathrm{Cu}_{\mathrm{x}} \mathrm{CO}_{3-\mathrm{x}} \mathrm{O}_{4}$ mixed oxides is, then, explained in terms of a mediated catalytic oxidation route between surface $\mathrm{Cu}(\mathrm{II})$-cyano complexes $\left.\left(\mathrm{Cu}_{(\text {spinel) }}\right)^{-} \mathrm{CN}^{-}\right)$and adjacent oxidized metal redox couple centers (either $\mathrm{Co}(\mathrm{IV})$ or $\mathrm{Cu}(\mathrm{III})$ ). On the contrary, despite cyanide is known to interact strongly with surface gold metal atoms, the segregation of phase domains probably prevents adsorbed cyanide on noble metal sites from being oxidized by $\mathrm{Co}(\mathrm{IV}) / \mathrm{Co}$ (III) redox sites on the spinel phase, thereby explaining a poor catalytic performance comparable to that of pure $\mathrm{CO}_{3} \mathrm{O}_{4}$ thin films.

These results remark the paramount importance of the anode design on its performance for electrochemical wastewater treatment, so the design of suitable electrode materials may lead to the development of new advantageous alternatives to expensive and fragile BDD.

\section{Acknowledgements}

Financial support from the Spanish Ministerio de Economía y Competitividad and FEDER funds (MAT2016-76595-R, IJCI-2014-20012) is gratefully acknowledged.

\section{REFERENCES}

[1] U.S. EPA. IRIS Toxicological Review of Hydrogen Cyanide and Cyanide Salts (Interagency Science Discussion Draft). U.S. Environmental Protection Agency, Washington, DC, EPA/635/R08/016D, 2010.

[2] A. Rubo, R. Kellens, J. Reddy, N. Steier, W. Hasenpusch, Alkali Metal Cyanides. Ullmann's Encyclopedia of Industrial Chemistry, first ed., Wiley-VCH Verlag GmbH \& Co. KGaA, Weinheim, 2006.

[3] Appendix A to Part 423 - 126 Priority Pollutants, in Code of Federal Regulations (United States). Title 40 - Protection of Environment. Vol. 29, 2014.

[4] Directive 2008/105/EC of the European Parliament and of the Council on Environmental Quality Standards.

[5] D.A. Dzombak, R.S. Ghosh, G.M. Wong-Chong, Cyanide in Water and Soil Chemistry, Risk, and Management, first ed., CRC Press/Taylor \& Francis Group, Boca Raton, 2006.

[6] R.R. Dash, A. Gaur, C. Balomajumder, Cyanide in industrial wastewaters and its removal: A review on biotreatment, J. Hazardous Materials 163 (2009) 1-11.

[7] G.H. Chen, Electrochemical technologies in wastewater treatment, Sep. Purif. Technol. 38 (2004) 11-41. 
[8] Ch. Comninellis, G. Chen, Electrochemistry for the Environment, Springer Science \& Business Media, New York, 2009.

[9] R. Berenguer, J.M. Sieben, C. Quijada, E. Morallón, Electrocatalytic degradation of phenol on Pt- and Ru-doped Ti/SnO ${ }_{2}$-Sb anodes in an alkaline medium, Appl. Catal. B: Environ. 199 (2016) 394-404.

[10] C.A. Martínez-Huitle, M.A. Rodrigo, I. Sirés, O. Scialdone, Electrochemical oxidation of organic pollutants for the wastewater treatment: direct and indirect processes, Chem. Soc. Rev. 35 (2006) 1324-1340.

[11] C.A. Martínez-Huitle, S. Ferro, Single and Coupled Electrochemical Processes and Reactors for the Abatement of Organic Water Pollutants: A Critical Review, Chem. Rev. 115 (2015) 13362-13407.

[12] R. Berenguer, A. La Rosa-Toro, C. Quijada, E. Morallón, Electrocatalytic oxidation of cyanide on copper-doped cobalt oxide electrodes, Appl. Catal. B: Environ. 207 (2017) 286-296.

[13] R. Berenguer, T. Valdés-Solís, A. B. Fuertes, C. Quijada, E. Morallón, Cyanide and phenol oxidation on nanostructured $\mathrm{CO}_{3} \mathrm{O}_{4}$ electrodes prepared by different methods, J. Electrochem. Soc. 155 (2008) K110-K115.

[14] A. La Rosa-Toro, R. Berenguer, C. Quijada, F. Montilla, E. Morallón, J.L. Vázquez, Preparation and characterization of copper-doped cobalt oxide electrodes, J. Phys. Chem. B 110 (2006) 24021-24029.

[15] R. Berenguer, A. La Rosa-Toro, C. Quijada, E. Morallón, Origin of the deactivation of spinel $\mathrm{Cu}_{x} \mathrm{CO}_{3-\mathrm{x}} \mathrm{O}_{4} / \mathrm{Ti}$ anodes prepared by thermal decomposition, J. Phys. Chem. C 112 (2008) 1694516952.

[16] R. Berenguer, J.M. Sieben, C. Quijada, E. Morallón, Pt- and Ru-doped $\mathrm{SnO}_{2}$-Sb anodes with high stability in alkaline medium, ACS Appl. Mater. Interf. 6 (2014) 22778-22789.

[17] C.S. Hofseth, T.W. Chapman, Electrochemical destruction of dilute cyanide by coppercatalyzed oxidation in a flow-through porous electrode, J. Electrochem. Soc. 146 (1999) 199207,

[18] L. Szpyrkowicz, S.N. Kaul, E. Molga, M. DeFaveri, Comparison of the performance of a reactor equipped with $\mathrm{Ti} / \mathrm{Pt}$ and an $\mathrm{SS}$ anode for simultaneous cyanide removal and copper recovery, Electrochim. Acta 46 (2000) 381-387.

[19] J. Lu, D.B. Dreisinger, W.C. Cooper, Anodic oxidation of copper cyanide on graphite anodes in alkaline solution, J. Appl. Electrochem. 32 (2002) 1119-1129.

[20] S.C. Cheng, M. Gatrell, T. Guena, B. MacDougall, The electrochemical oxidation of alkaline copper cyanide solutions, Electrochim. Acta 47 (2002) 3245-3256.

[21] V. Reyes-Cruz, I. González, M.T. Oropeza, Voltammetric evaluation of the electrode material on the oxidation of cyanide catalyzed by copper ions, J. Solid State Electrochem. 9 (2005) 566-573.

[22] B. Wels, D.C. Johnson, Electrocatalysis of anodic oxygen transfer reactions: oxidation of cyanide at electrodeposited copper oxide electrodes in alkaline media, J. Electrochem. Soc. 137 (1990) 2785-2791. 
[23] L. Szpyrkowicz, G.H. Kelsall, R.M. Souto, F. Ricci, S.N. Kaul, Hydrodynamic effects on the performance of an electrochemical reactor for destruction of copper cyanide-Part 1: In situ formation of the electrocatalytic film, Chem. Eng. Sci. 60 (2005) 523-533.

[24] T. Arikado, C. Iwakura, H. Yoneyama, H. Tamura, Anodic oxidation of potassium cyanide on the graphite electrode, Electrochim. Acta 21 (1976) 1021-1027.

[25] F. Hine, M. Yasuda, T. lida, Y. Ogata. On the oxidation of cyanide solutions with lead dioxide coated anode, Electrochim. Acta 31 (1986) 1389-1395.

[26] A. Valiūnienė, G. Baltrūnasa, V. Keršulytè, Ž. Margarian, G. Valinčius, The degradation of cyanide by anodic electrooxidation using different anode materials, Process Saf. Environ. Prot. 91 (2013) 269-274

[27] A. Stavart, A. Van Lierde, Electrooxidation of cyanide on cobalt oxide anodes, J. Appl. Electrochem. 31 (2001) 469-474.

[28] P. Cañizares, M. Díaz, J.A Domínguez, J. Lobato, M.A Rodrigo, Electrochemical treatment of diluted cyanide aqueous wastes, J. Chem. Technol. Biotechnol. 80 (2005) 565-573.

[29] C.S. Fugivara, P.T.A. Sumodjo, A.A. Cardoso, A.V. Benedetti, Electrochemical decomposition of cyanides on tin dioxide electrodes in alkaline media, Analyst 121 (1996) 541545.

[30] M.R.V. Lanza, R. Bertazzoli, Cyanide Oxidation from Wastewater in a Flow Electrochemical Reactor, Ind. Eng. Chem. Res. 41 (2002) 22-26.

[31] K.R. Dunbar, R.A. Heintz, Chemistry of Transition Metal Cyanide Compounds: Modern Perspectives, in: K.D. Karlin (Ed.), Progress in Inorganic Chemistry, Volume 45, John Wiley \& Sons Inc., Hoboken, 1996, pp. 283-391.

[32] N. Fradette, B. Marsan, Surface studies of $\mathrm{Cu}_{x} \mathrm{Co}_{3-\mathrm{x}} \mathrm{O}_{4}$ electrodes for the electrocatalysis of oxygen evolution, J. Electrochem. Soc. 145 (1998) 2320-2327.

[33] J.L. Gautier, E. Trollund, E. Ríos, P. Nkeng, G. Poillerat, Characterization of thin $\mathrm{CuCO}_{2} \mathrm{O}_{4}$ films prepared by chemical spray pyrolysis. Study of their electrochemical stability by ex situ spectroscopic analysis, J. Electroanal. Chem. 428 (1997) 47-56.

[34] R.J. Hill, J.R Craig, G.V. Gibbs, Systematics of the spinel structure type, Phys. Chem. Minerals 4 (1979) 317-339.

[35] A.C. Tavares, M.A.M. Cartaxo, M.I. da Silva Pereira, F.M. Costa, Electrochemical study of spinel oxide systems with nominal compositions $\mathrm{Ni}_{1-x} \mathrm{Cu}_{x} \mathrm{Co}_{2} \mathrm{O}_{4}$ and $\mathrm{NiCO}_{2-y} \mathrm{Cu}_{y} \mathrm{O}_{4}$, J. solid State Electrochem. 5 (2001) 57-67.

[36] M.P. Casaletto, A. Longo, A. Martorana, A. Prestianni, A.M. Venezia, XPS study of supported gold catalysts: the role of $\mathrm{Au}^{0}$ and $\mathrm{Au}^{+\delta}$ species as active sites, Surf. Interface Anal. 38 (2006) 215-218.

[37] C.S. Hofseth, T.W. Chapman, Rotating ring-disk electrode studies of cyanocuprous ion oxidation on platinum, J. Electrochem. Soc. 138 (1991) 2321-2327.

[38] C.S. Hofseth, T.W. Chapman, Indirect electrochemical processes at a rotating disk electrode: Catalytic alkaline cyanide oxidation, J. Electrochem. Soc. 139 (1992) 2525-2529. 
[39] F. Montilla, E. Morallón, A. De Battisti, A. Benedetti, H. Yamashita, J.L. Vázquez, Preparation and characterization of antimony-doped tin dioxide electrodes. Part 2. XRD and EXAFS characterization, J. Phys. Chem. B 108 (2004) 5044-5050.

[40] M. Fleischmann, Z.Q. Tian, L.J. Li, Raman spectroscopy of adsorbates on thin film electrodes deposited on silver substrates, J. Electroanal. Chem. 217 (1987) 397-410.

[41] R.E. Hester, Raman spectroscopic studies of species in situ at electrode surfaces, in: R.G. Compton and A. Hamnett (Eds.), Comprehensive Chemical Kinetics. New techniques for the study of electrodes and their reactions, Volume 29, Elsevier, Amsterdam, 1989, pp. 79-104.

[42] T. Iwasita, F.C. Nart, In-situ Fourier Transform Infrared Spectroscopy. A tool to characterize the metal-electrolyte interface at a molecular level, in: H. Gerischer, C.W. Tobias (Eds.), Advances in Electrochemical Science and Engineering, Volume 4, Wiley-VCH Verlag GmbH \& Co. KGaA, Weinheim, 1995, pp. 123-216.

[43] H. Seki, In situ infrared spectroscopy of the electrode-electrolyte interface, IBM J. Res. Develop. 37 (1993) 227-241.

[44] F. Huerta, E. Morallón, C. Quijada, J.L. Vázquez, L.E.A. Berlouis, Potential modulated reflectance spectroscopy of $\mathrm{Pt}(111)$ in acidic and alkaline media: cyanide adsorption, J. Electroanal. Chem. 463 (1999) 109-115.

[45] F. Huerta, E. Morallón, J.L. Vázquez, The surface electrochemistry of cyanide ion, Curr. Top. Electrochem. 10 (2004) 211-223.

[46] G.L. Beltramo, T.E. Shubina, S.J. Mitchell, M.T.M. Koper, Cyanide adsorption on gold electrodes: a combined surface enhanced Raman spectroscopy and density functional theory study, J. Electroanal. Chem. 563 (2004) 111-120.

[47] M.-S Liao, X. Lü, Q.-E. Zhang, Cyanide adsorbed on coinage metal electrodes: A relativistic density functional investigation, Int. J. Quantum Chem. 67 (1998) 175-185.

[48] H. Tamura, T. Arikado, H. Yoneyama, Y. Matsuda, Anodic oxidation of potassium cyanide on platinum electrode, Electrochim. Acta 19 (1974) 273-277. 


\section{Highlights}

\section{Electro-oxidation of cyanide on active and non-active anodes: designing the electrocatalytic response of cobalt spinels}

1. $\mathrm{Au} / \mathrm{Cu}$-doped $\mathrm{Co}$ oxides are compared with graphite, $\mathrm{BDD}$ and $\mathrm{SnO}_{2}-\mathrm{Sb}$ for $\mathrm{CN}^{-}$ oxidation

2. The dopant nature plays a key role on the electrocatalytic behavior of Co spinels

3. $\mathrm{Cu}$ is incorporated into the spinel structure while $\mathrm{Au}$ segregates as particles

4. Inexpensive "active" $\mathrm{Cu}$-Co spinels exhibit higher efficiencies than "non-active" BDD

5. Anode design is crucial for the feasibility of electrochemical wastewater treatment 